\title{
A COVID-19 case report from asymptomatic contact: implication for contact isolation and incubation management
}

Chang-Qiang Zhu', Shi-Ding Gao², Yan Xu³ ${ }^{3}$ Xiao-Hong Yang ${ }^{1}$, Fu-Qiang Ye ${ }^{1}$, Le-Le Ai ${ }^{1}$, Rui-Chen Lv ${ }^{1}$, Bin Zhang ${ }^{1}$, Yin Li ${ }^{1}$, Heng Lv ${ }^{1}$, Yun-Sheng Liư ${ }^{4}$, Chun-Meng Shi ${ }^{4}$, Chun-Hui Wang ${ }^{1}$ and Wei-Long Tan ${ }^{*}$

\begin{abstract}
Background: As of 2 March, 2020, at least 80151 coronavirus disease 2019 (COVID-19) cases were reported in China. Most of the patients had a history of visiting Hubei Province or contacting with people who had ever stayed in or passed by Hubei Province or were exposed to symptoms. Some patients got infected through only asymptomatic contact. This study aimed to report the epidemic features and lab identification of a patient confirmed with COVID-19 infection through only asymptomatic contact.

Case presentation: A 44-year-old man, who lived in Nanchang, Jiangxi Province, China until 6 March 2020, suffered from cough on 27 January 2020. Fever symptoms appeared on 28 January, with a maximum temperature of $38.8^{\circ} \mathrm{C}$, accompanied by cough, sore throat, headache, fatigue, muscle ache, joint ache, and other symptoms. The symptoms continued until he was hospitalized on 30 January. Coronavirus conventional polymerase chain reaction assay was positive for the throat swab sample. The patient, along with his wife and son, drove from Nanchang to back to Honghu City, Hubei Province, on 23 January 2020. After staying with his parents and brother's family for 3 days, the patient drove back to Nanchang and arrived on 25 January. On the way back home, they stopped by Tongshan service area, Hubei Province, without any close contact with other people. After arriving home in Nanchang City, Jiangxi Province, none of them left their residence. In addition, his parents stayed at home for 20 days with his younger brother's family before they got back. His younger brother and one of his brother's children visited Wuhan on 5 January and came home on 6 January 2020.
\end{abstract}

Conclusions: This report suggested that, in the early phase of COVID-19 pneumonia, routine screening could miss patients who were virus carriers. Highlighting travel history is of paramount importance for the early detection and isolation of severe acute respiratory syndrome coronavirus 2 cases.

Keywords: COVID-19, Coronavirus, Infection, Particular contacting

\footnotetext{
* Correspondence: njcdc@163.com

${ }^{1}$ Centre for Diseases Prevention and Control of Eastern Theater, Nanjing 210002, China

Full list of author information is available at the end of the article
}

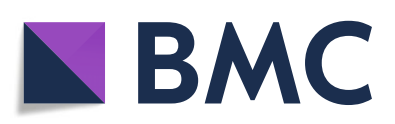

(c) The Author(s). 2020 Open Access This article is licensed under a Creative Commons Attribution 4.0 International License, which permits use, sharing, adaptation, distribution and reproduction in any medium or format, as long as you give appropriate credit to the original author(s) and the source, provide a link to the Creative Commons licence, and indicate if changes were made. The images or other third party material in this article are included in the article's Creative Commons licence, unless indicated otherwise in a credit line to the material. If material is not included in the article's Creative Commons licence and your intended use is not permitted by statutory regulation or exceeds the permitted use, you will need to obtain permission directly from the copyright holder. To view a copy of this licence, visit http://creativecommons.org/licenses/by/4.0/ The Creative Commons Public Domain Dedication waiver (http://creativecommons.org/publicdomain/zero/1.0/) applies to the data made available in this article, unless otherwise stated in a credit line to the data. 


\section{Background}

Coronavirus $(\mathrm{CoV})$ is a positive-sense single-stranded RNA virus [1]. Many kinds of mammals, such as hedgehog, pangolin, civet, and bat, can serve as storage hosts of coronavirus [2-6]. Six CoVs have been identified to be pathogenic, including four endemic (HCoV-OC43, -229E, -NL63, and -HKU1) and two epidemic (SARS-CoV and MERS-CoV) viruses [7, 8]. A cluster of cases of pneumonia was reported in Wuhan, Hubei Province, China, in December 2019. On 11 February 2020, the diseases named as coronavirus disease 2019 (COVID-19) by the World Health Organization (WHO), and Coronavirus Study Group (CSG) of the International Committee proposed to name the new coronavirus as SARS-CoV-2. Up to 2 March 2020, at least 80151 cases were reported (http://www.gov.cn/xinwen/2020-03/03/content_5486171.htm). Most of the patients had a history of visiting Hubei Province or contacting people who had ever stayed in or passed by Hubei Province, or were exposed to symptoms [9]. Some patients got infected through only asymptomatic contact. This study aimed to report the epidemic features and lab identification of a patient confirmed with COVID-19 infection through only asymptomatic contact (Fig. 1).

\section{Case presentation}

A 44-year-old man, who lived in Nanchang, Jiangxi Province, China, got a fever of $38.8^{\circ} \mathrm{C}$ on 27 January 2020 . He wore a mask and drove himself to see a doctor in a local hospital in Nanchang on 30 January 2020. He was immediately hospitalized in an isolation room. The PCR assay result was positive for the throat swab sample using a SARS-COV-2 real-time RT-PCR Kit (Fig. 2). The patient was an instructor in a university and visited the city of Huangmei, Hubei Province. He stayed with his parents and his brother's family, but denied any exposure to a febrile patient or wild animals, or visits to wet markets, including the Seafood Market in Wuhan.

Before the onset of symptoms, the patient, along with his wife and son, drove from Nanchang to Honghu City, Hubei Province, on 23 January 2020, where his parents and brother lived. They did not stop by any of the expressway service area. After arriving, they stayed at home and did not visit any public place in Honghu City. In addition, his parents stayed at home for 20 days with his younger brother's family before they got back. His younger brother and one of his brother's children visited Wuhan on 5 January and came home on 6 January 2020. After staying with his parents and brother's family for 3 days, the patient drove back to Nanchang and arrived on 25 January. On the way back home, they stopped by Tongshan service area, Hubei Province, without any close contact with other people. After arriving home in Nanchang City, Jiangxi Province, none of them left their residence.

The patient began to have a cough on 27 January 2020, and took cefalexin capsules by himself. Fever symptoms appeared on 28 January, with a maximum temperature of $38.8^{\circ} \mathrm{C}$, accompanied by cough, sore throat, headache, fatigue, muscle ache, joint ache, and other symptoms (Fig. 3). The symptoms continued until he went to the doctor. At the hospital's fever clinic, he underwent blood routine examination and lung computed tomography (CT) examination (Fig. 4).

He was not obese and had no previous basic disease. On admission (30 January 2020), the physical examination

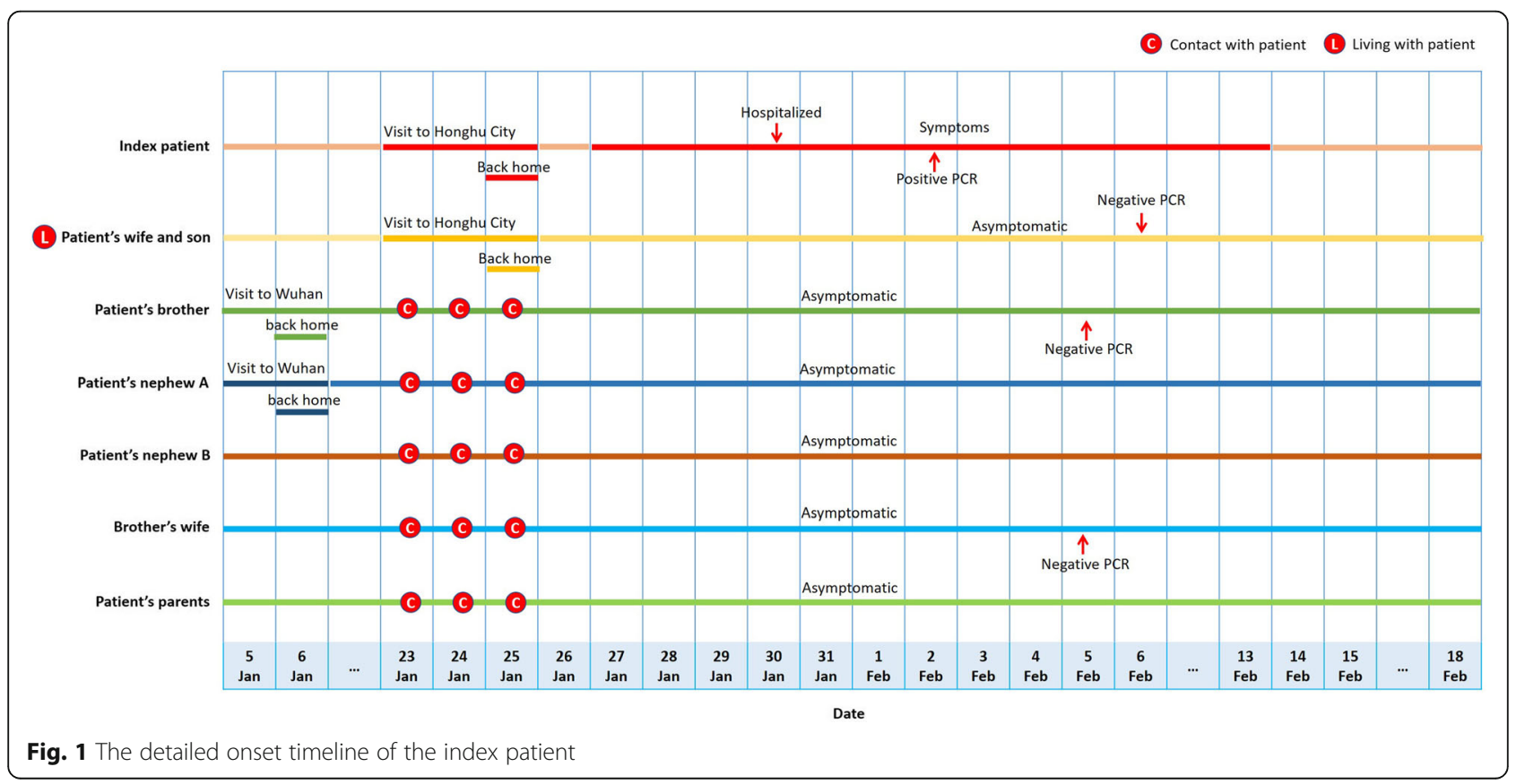



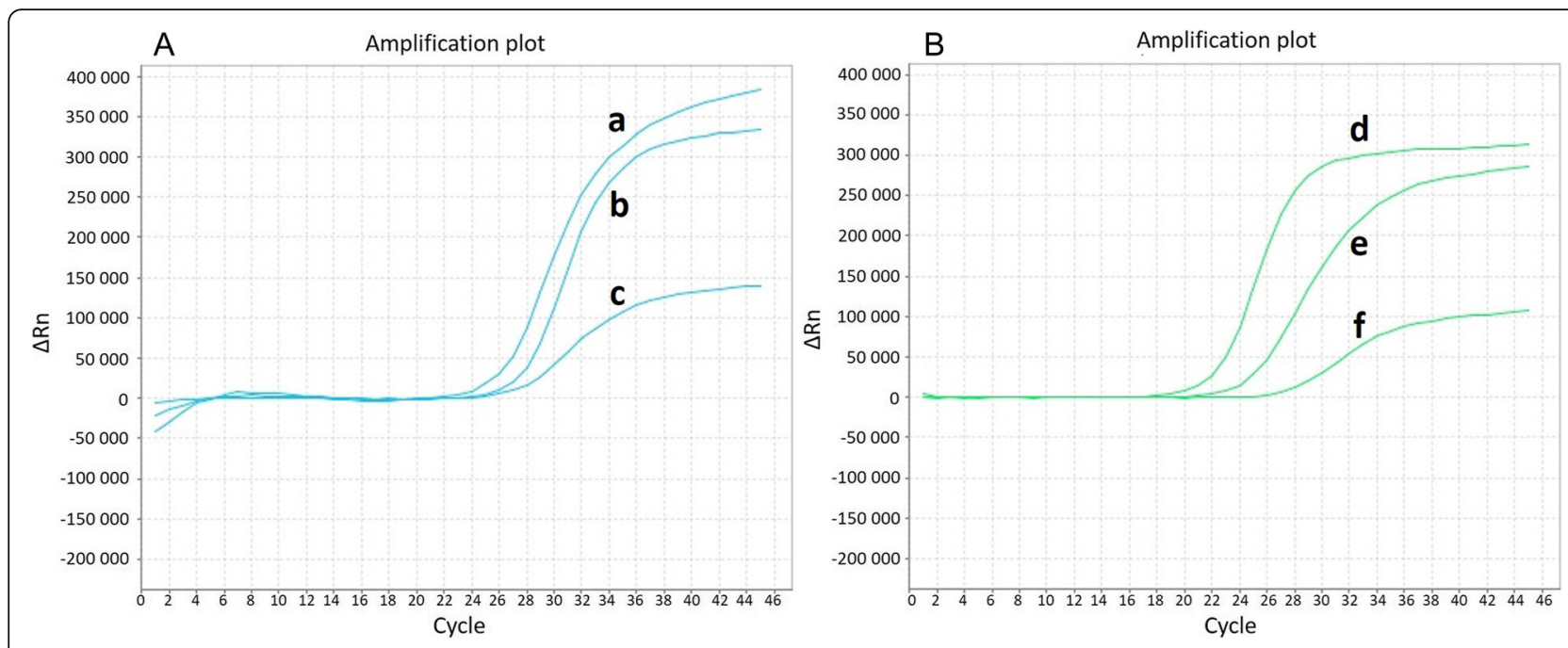

Fig. 2 Imaging of the patient using reverse transcription PCR. A Positive control of ORF1ab (a), N (b), and E (c). B Specimen detection of ORF1ab (d), N (e), and $E(f)$

revealed a body temperature of $38.8^{\circ} \mathrm{C}$, a respiratory rate of 19-21 breaths per minute, a pulse of $62-88$ per minute, and a blood pressure of $76 / 128 \mathrm{mmHg}$. The initial chest radiography showed a glass density shadow of both lungs (Fig. 4a-b).

On 31 January 2020, the blood routine examination revealed the following: white blood cell (WBC) count: $7.4 \times 10^{9} / \mathrm{L}$; lymphocyte $(\mathrm{LY})$ count: $0.6 \times 10^{6} / \mathrm{L}$. Another routine test on 31 January showed the WBC count of $4.4 \times 10^{9} / \mathrm{L}$ and a decreased C-reactive protein level of $4.9 \mathrm{mg} / \mathrm{L}$. The lung CT examination at 8:00 PM showed lung lesions significantly larger compared with those on the previous day.

However, high-resolution computed tomography on 3 February 2020 (day 8 of illness), revealed multiple, ground-glass opacities located in both subpleural spaces
(Fig. 4c-d). The blood routine examination showed mild changes in neutrophil and lymphocyte counts. During admission, he developed nasal congestion, cough, and pleuritic chest discomfort.

He received the following medicines treatment during hospitalization for 18 days. Including: oral lopinavir/ritonavir $(6.67 / 1.67 \mathrm{mg} / \mathrm{kg} /$ day $[12 \mathrm{~h}])$, aerosol inhalation of interferon alpha $(0.833 \mu \mathrm{g} / \mathrm{kg} /$ day [24 h]), oral lianhuaqingwen capsule $(23.33 \mathrm{mg} / \mathrm{kg} /$ day $[8 \mathrm{~h}])$, oral suhuang zhike capsule $(22.5 \mathrm{mg} / \mathrm{kg} /$ day $[8 \mathrm{~h}])$, enteral nutrition $(0.833 \mathrm{~g} / \mathrm{kg} /$ day [6 $\mathrm{h}])$, thymalfasin for injection $(26.67 \mu \mathrm{g} /$ $\mathrm{kg} / 3$ days $[72 \mathrm{~h}])$, xuebijing injection $(1.67 \mathrm{ml} / \mathrm{kg} /$ day [12 h]). In addition, the hormone was only used for 5 days, methylprednisolone sodium succinate $(0.667 \mathrm{mg} / \mathrm{kg} /$ day [24 h]) for 3 days, methylprednisolone sodium succinate $(0.333 \mathrm{mg} / \mathrm{kg} /$ day $[24 \mathrm{~h}])$ for 1 day, methylprednisolone

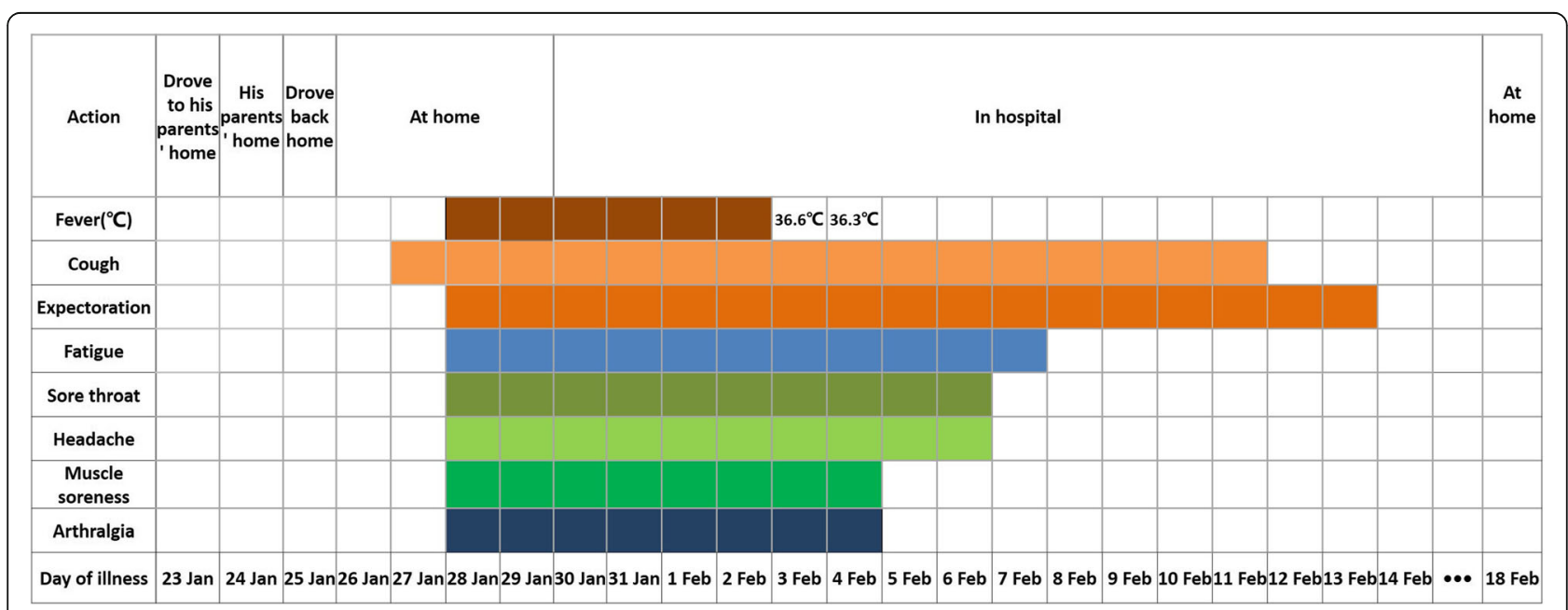

Fig. 3 Symptoms and maximum body temperatures according to the day of illness between 27 January and 18 February 2020 


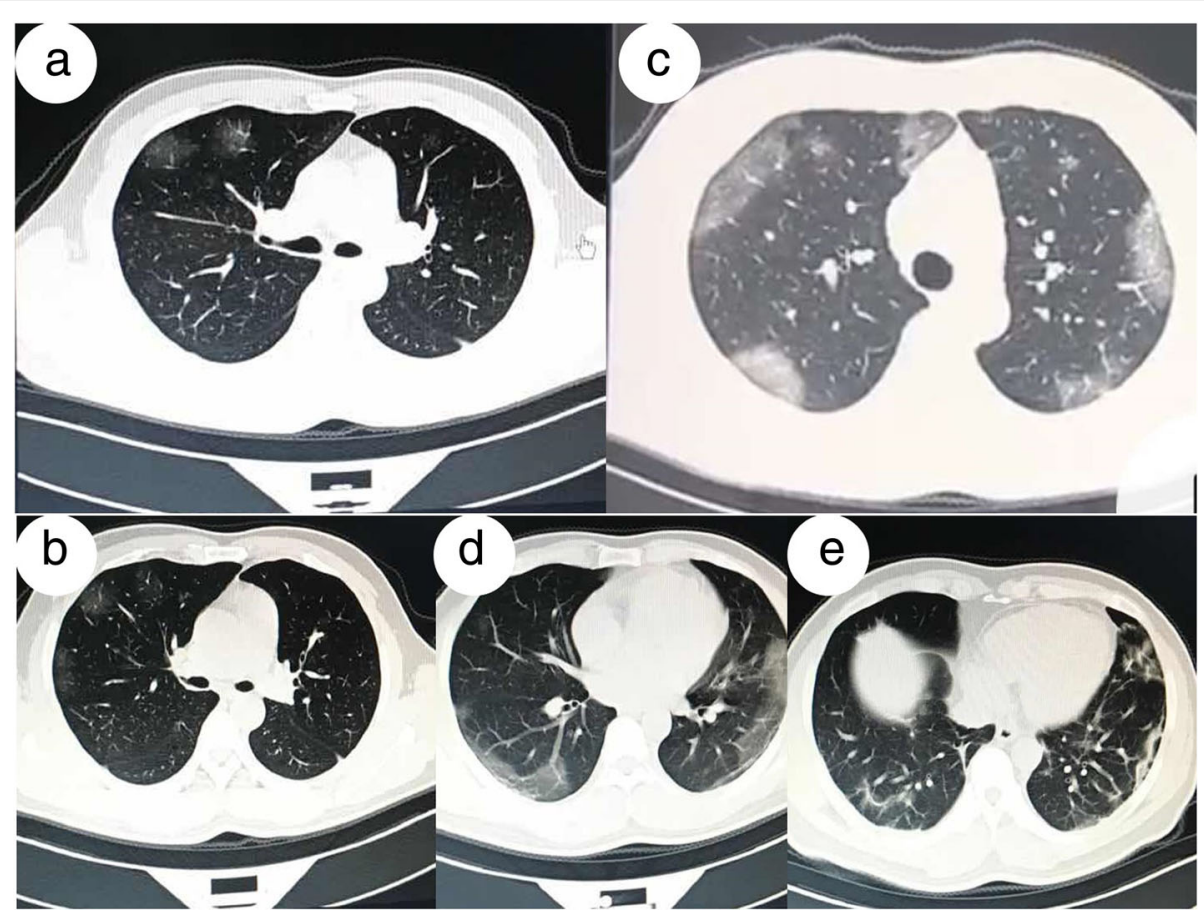

Fig. 4 Chest imaging of the patient. $\mathbf{a}$ and $\mathbf{b}$ Chest CT scans of the lung on 30 January and 31 January 2020 (3-4 days after the symptom onset) revealed slight pulmonary infiltration. $\mathbf{c}$ and $\mathbf{d}$ CT scans taken on 3 February 2020 (8 days after the symptom onset) showed obvious pulmonary infiltrates. e CT scans taken on 10 February 2020 (15 days after the symptom onset). HRCT, High-resolution computed tomography

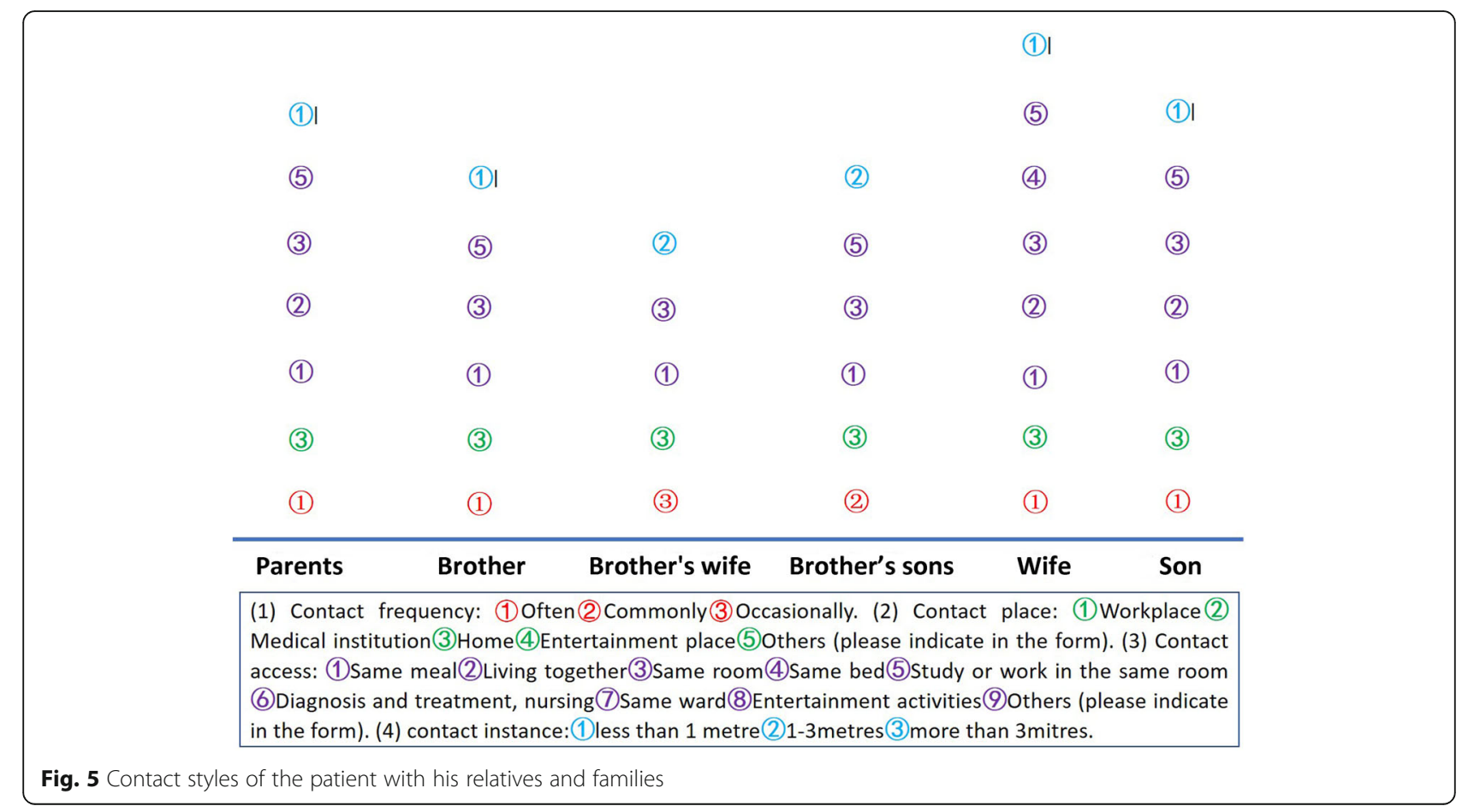


sodium succinate $(0.167 \mathrm{mg} / \mathrm{kg} /$ day $[24 \mathrm{~h}])$ for 1 day, and then stopping use hormone.

\section{Further tracing of the source of virus}

Before the patient's visit to Honghu, his relatives, including his parents and brother's family, had no disease or infection through contact or clustering. After he was hospitalized, the results of the coronavirus conventional PCR assay of his wife, son, brother, and brother's wife performed once every other day were negative. No farmer's market was located near their residence. The patient did not go to any farmer's market. His wife and son, who were two close contacts with a final contact on 30 January 2020, had no symptoms or signs till 18 February 2020 (Figs. 5 and 6).

\section{Discussion and conclusions}

This patient was diagnosed with SARS-CoV-2 infection. His PCR test was positive, but the test for seasonal influenza and adenovirus infection was negative, despite flulike symptoms and pneumonia during the first week of illness. In this case report, the COVID-19 infection was diagnosed by a PCR test or based on clinical symptoms combined with a CT scan [10].

The duration from infection to the appearance of symptoms of SARS-CoV-2 was not exactly known [11]. Generally, it was thought to be 14 days, but a research group at Guangzhou reported the longest incubation period of 24 days [12]. In addition, asymptomatic transmission of SARS-CoV-2 is an important topic and asymptomatic infections of SARS-CoV-2 could complicate disease control [13]. The report of "Diamond Princess" showed that a large number of asymptomatic carriers might remain undiscovered in the community
[14]. Mao et al. reported that the asymptomatic ratio of COVID-19 was $2.6 \%$ (2 out of 78 confirmed cases) [15]. Nishiura et al. estimated $41.6 \%$ of cases among 565 Japanese individuals evacuated from Wuhan, China were asymptomatic case [16]. As of 4 April 2020, 150 asymptomatic case out of 915 confirmed cases were reported in Hong Kong, giving a ratio of $16.4 \%$ [17]. Hu et al. provided evidence for transmission from an asymptomatic infector to close contacts that result in severe COVID19 pneumonia [18]. These findings suggest that asymptomatic carriers should be considered a source of COVID-19 infection. In this study, the patient's wife, son, parents, and brother's family had no symptoms or signs between 5 January and 18 February 2020. After the patient was hospitalized, RT-PCR tests of his wife, son, brother, and brother's wife performed once every other day were negative. Their PCR results were negative probably because the virus was eliminated due to the longtime interval or the viral load was too low to be detected, or the test results were false negative. Moreover, the patient's parents and nephews A and B did not undergo the RT-PCR test for SARS-CoV-2 infection, and hence whether they were carriers was not confirmed. No suspected or confirmed cases were reported in Nanchang within 14 days of the departure of the patient from the site on 23 January. Therefore, it was difficult to predict who might have passed the virus to the patient; any of the relatives could have served as an intermediary of the virus except for his wife and son (Fig. 7).

This case report highlighted the possibility of developing SARS-CoV-2 infection through an asymptomatic contact. It indicated the need for contact isolation, especially for those who returned from the epidemic area without any symptoms $[19,20]$. In addition, this report

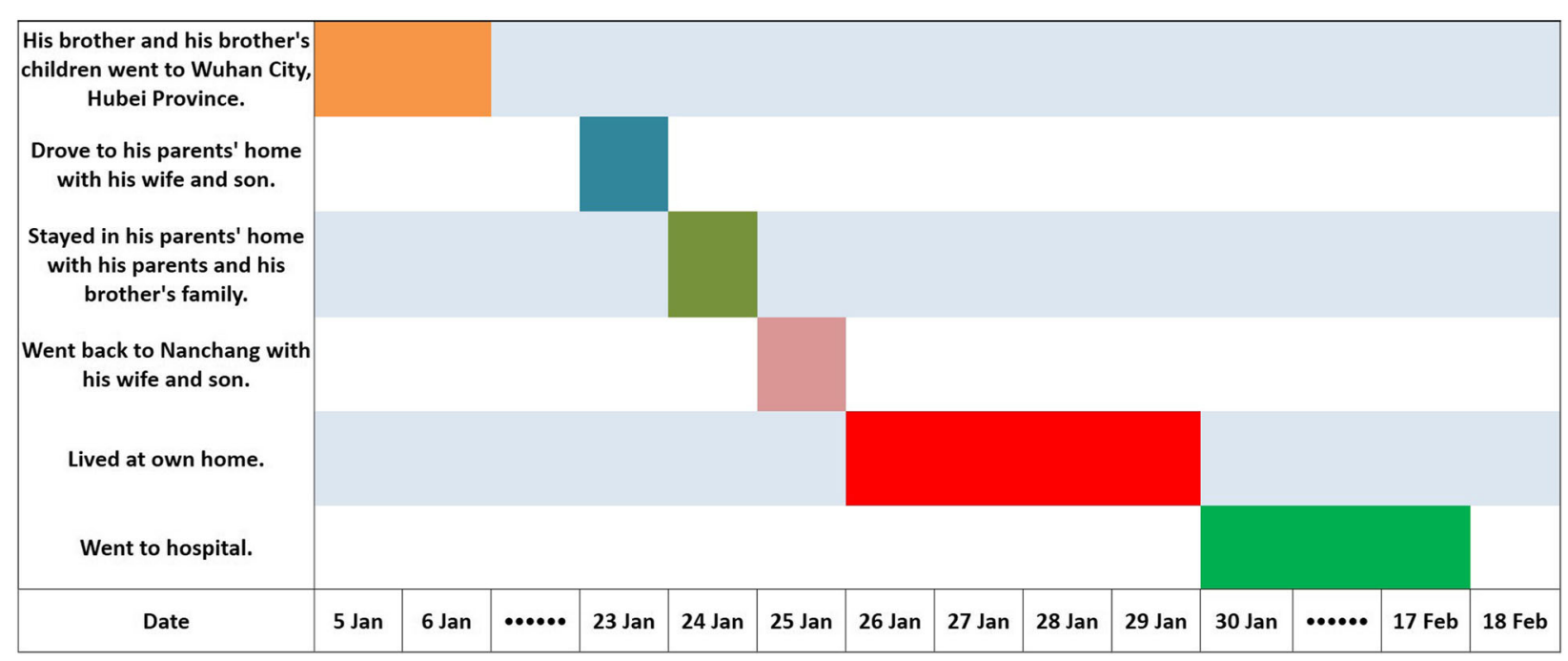

Fig. 6 Travel and residence history of the patient and his family 


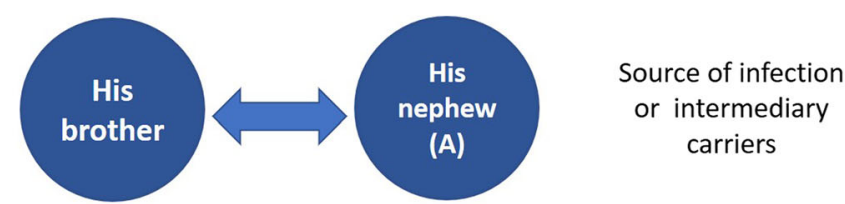

Possible intermediate carriers
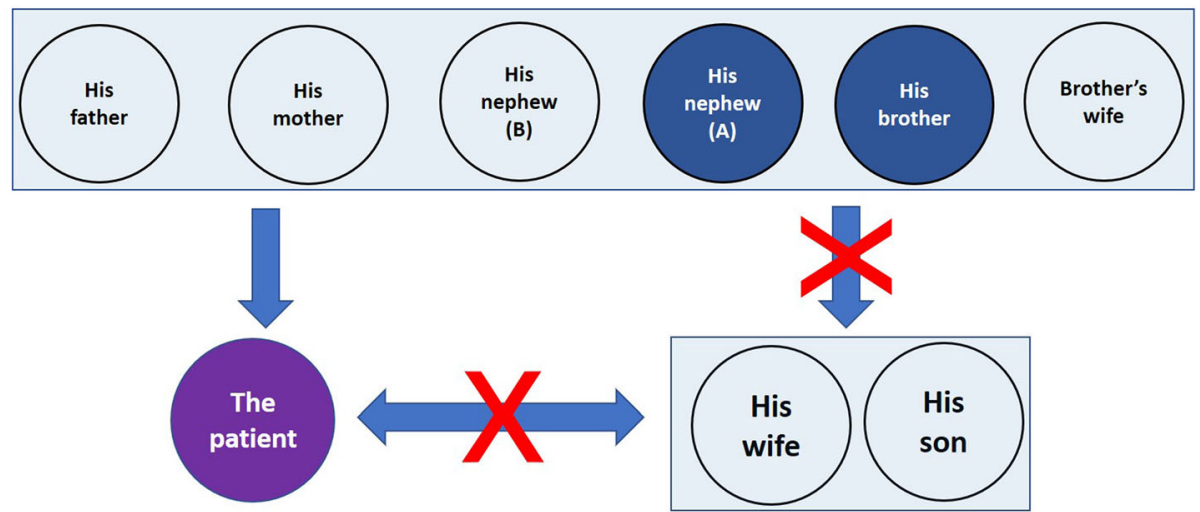

Fig. 7 Possible transmission of the virus among relative

suggested that, in the early phase of COVID-19, routine screening could miss diagnosing patients who were virus carriers. The frequency of such transmissions of asymptomatic infection remains to be determined. The scale of transmission through an asymptomatic contact during the early phase of infection should be explored urgently.

In conclusion, this report indicated that highlighting travel history is of paramount importance for the early detection and isolation of SARS-CoV-2 cases. The findings might be used as a reference for the prevention and control during this global outbreak of COVID-19.

\section{Abbreviations}

CoV: Coronavirus; COVID-19: Coronavirus Disease 2019; CRP: C-reactive protein; CT: Computed tomography; HRCT: High-resolution computed tomography; LY: Lymphocyte; MERS: Middle East respiratory syndrome; nCoV: Novel coronavirus; PCR: Polymerase chain reaction; PM: Post meridiem; SARS: Severe Acute respiratory syndrome; WBC: White blood cell

\section{Acknowledgments}

The authors thank Bin Zheng from the Centre for Diseases Prevention and Control of Eastern Theater for his assistance in reviewing the case report.

\section{Authors' contributions}

C-QZ, S-DG, and W-LT wrote the manuscript and carried out the analysis. CHW and B-Z designed and supervised this study. YL, HL, Y-SL, YX and C-MS investigated the case. $X-H Y, F Y, L-L A$, and $R-C L$ were involved in laboratory works. All authors read and approved the final manuscript.

\section{Authors' information}

Not applicable.

\section{Funding}

This study was funded by the Chongqing Research Program of Technology Innovation and Application Development on 2019 Novel Coronavirus-
Infected Pneumonia (CSTC2020jscx-fyzx0009), National Postdoctoral Special Aid (2016 T91011).

Availability of data and materials

All original data and materials are available from the corresponding author upon request.

\section{Ethics approval and consent to participate}

The ethics committee approved the study. Ethical approval was granted by Ethics Review Committee of Centre for Diseases Prevention and Control of Eastern Theater (Ethics Committee No. 2020002). Written informed consent was obtained from the patient following the Declaration of Helsinki.

\section{Consent for publication}

The case described here provided written consent for the publication of this case report.

\section{Competing interests}

The authors declare no competing interests.

\section{Author details}

${ }^{1}$ Centre for Diseases Prevention and Control of Eastern Theater, Nanjing 210002, China. ${ }^{2}$ The No: 908 Hospital, Nanchang 330000, China. ${ }^{3}$ Centre for Diseases Prevention and Control of Jiangsu Province, Nanjing 210009, China. ${ }^{4}$ Army Medical University, Chongqing 431000, China.

Received: 3 March 2020 Accepted: 1 June 2020

Published online: 19 June 2020

\section{References}

1. Wu F, Zhao S, Yu B, Chen YM, Wang W, Song ZG, et al. A new coronavirus associated with human respiratory disease in China. Nature. 2020. https:// doi.org/10.1038/s41586-020-2008-3.

2. Ren $L L$, Wang $Y M, W u Z Q$, Xiang $Z C$, Guo L, Xu T, et al. Identification of a novel coronavirus causing severe pneumonia in human: a descriptive study. Chin Med J. 2020. https://doi.org/10.1097/CM9.0000000000000722.

3. Lu R, Zhao X, Li J, Niu P, Yang B, Wu H, et al. Genomic characterisation and epidemiology of 2019 novel coronavirus: implications for virus origins and receptor binding. Lancet. 2020;395:565-74 pii: S0140-6736(20)30251-8. 
4. Yaghoubi H, Ghaly A, Karimi V, Ghafouri SA, Hashemzadeh M, Hosseini H, et al. Molecular detection of gamma coronaviruses in bird parks of Iran. Archives Razi Institute. 2019;74(4):349-55.

5. Susanna KP, Hayes KH, Antonio CP, Rachel YY, Carol SF, Kenneth SM, et al. Identification of a novel betacoronavirus (Merbecovirus) in Amur Hedgehogs from China. Viruses. 2019;11(11):E980. https://doi.org/10.3390/v11110980.

6. Hu D, Zhu C, Wang Y, Ai L, Yang L, Ye F, et al. Genomic characterization and infectivity of a novel SARS-like coronavirus in Chinese bats. Emerg Microb Infect. 2018;7:154

7. Wan YS, Shang J, Graham R, Baric RS, Li F. Receptor recognition by novel coronavirus from Wuhan: An analysis based on decade-long structural studies of SARS. J Virol. 2019. https://doi.org/10.1128/JVI.00127-20.

8. Li B, Si HR, Zhu Y, Yang XL, Anderson DE, Shi ZL, et al. Discovery of bat coronaviruses through surveillance and probe capture-based nextgeneration sequencing. mSphere. 2020:5:e00807-19.

9. Zhou $P$, Yang XL, Wang XG, Hu B, Zhang L, Zhang W, et al. Discovery of a novel coronavirus associated with the recent pneumonia outbreak in humans and its potential bat origin. Nature. 2020. https://doi.org/10.1038/ s41586-020-2012-7.

10. Chen L, Liu W, Zhang Q, Xu K, Ye G, Wu W, et al. RNA based mNGS approach identifies a novel human coronavirus from two individual pneumonia cases in 2019 Wuhan outbreak. Emerg Microbes Infect. 2020; 9(1):313-9.

11. Kim JY, Pyoeng GC, Yoonju O, Kyung JO, Jinsil K, So JP, et al. The first case of 2019 novel coronavirus pneumonia imported into Korea from Wuhan, China: implication for infection prevention and control measures.J Korean Med Sci. 2020;35(5):e61.

12. Guan WJ, Ni ZY, Hu Y, Laing WH, Ou CQ, He JX, et al. Clinical characteristics of 2019 novel coronavirus infection in China. medRxiv. 2020. https://doi.org/ 10.1101/2020.02.06.20020974.

13. Qiu J. Covert coronavirus infections could be seeding new outbreaks. Nature. 2020. https://doi.org/10.1038/d41586-020-00822-x.

14. Wikipedia. Diamond Princess (ship). https://en.wikipedia.org/wiki/ Diamond Princess_(ship). 2020.

15. Mao ZQ, Wan R, He LY, Hu YC, Chen W. The enlightenment from two cases of asymptomatic infection with SARS-CoV-2: is it safe after 14 days of isolation? Int J Infect Dis. 2020;95. https://doi.org/10.1016/j.ijid.2020.03.041.

16. Mizumoto K, Kagaya K, Zarebski A, Chowell G. Estimating the asymptomatic proportion of coronavirus disease 2019 (COVID-19) cases on board the diamond princess cruise ship, Yokohama, Japan, 2020. Euro Surveill. 2020; 25(10):2000180.

17. He D, Zhao S, Lin Q, Zhuang Z, Cao P, Wang MH, Yang L. The relative transmissibility of asymptomatic cases among close contacts. Int J Infect Dis. 2020:94:145-7.

18. Hu Z, Song $C, X u C$, Jin $G$, Chen $Y, X u X, M a ~ H$, et al. Clinical characteristics of 24 asymptomatic infections with COVID-19 screened among close contacts in Nanjing, China. Sci Chin Life Sci. 2020;63(5):706-11.

19. Du Z, Wang L, Cauchemez S, Xu X, Wang X, Cowling BJ, et al. Risk for transportation of 2019 novel coronavirus disease from Wuhan to other cities in China. Emerg Infect Dis. 2020;26(5). https://doi.org/10.3201/eid2605. 200146

20. Velavan TP, Meyer CG. The Covid-19 epidemic. Tropical Med Int Health. 2020. https://doi.org/10.1111/tmi.13383.

Ready to submit your research? Choose BMC and benefit from:

- fast, convenient online submission

- thorough peer review by experienced researchers in your field

- rapid publication on acceptance

- support for research data, including large and complex data types

- gold Open Access which fosters wider collaboration and increased citations

- maximum visibility for your research: over $100 \mathrm{M}$ website views per year

At BMC, research is always in progress.

Learn more biomedcentral.com/submissions 